\title{
Prognosis for vision and fundus changes in patients with proliferative diabetic retinopathy
}

\section{P. H. MADSEN}

From the Departments of Ophthalmology and Internal Medicine, the University Hospital, Aarhus, Denmark

Diabetic retinopathy has become one of the major causes of adult blindness in many countries (Winter, I960; Vedel-Jensen, I962; Caird and Garrett, I963; Lee, McMeel, Schepens, and Field, I966; Caird, Burditt, and Draper, I968; Caird, Pirie, and Ramsell, 1969; Lindstedt, 1969). Proliferative retinopathy is the severest form of the diabetic fundus disease, and although it occurs in only a small percentage of the patients in a nonselected diabetic population, proliferative retinopathy is particularly feared, as it is often followed by rapid loss of vision. Drastic therapeutic measures, such as photocoagulation, hypophysectomy, and adrenalectomy, have been applied in an attempt to stop the progression of this late diabetic manifestation.

The purpose of the present paper is to describe the development of the fundus changes and to give an impression of the visual prognosis in diabetics with proliferative retinopathy.

\section{Material}

The series consists of 68 patients ( 38 men and 30 women) with proliferative diabetic retinopathy from the Departments of Ophthalmology and Internal Medicine, the University Hospital, Aarhus. The patients were examined repeatedly by the author during the 5 -year period $1963-68$, and the retinal lesions were repeatedly recorded by fundus drawings and photographs. In many of the patients, proliferative retinopathy had been diagnosed before 1963 , and the results of these early observations were incorporated in the present study.

Hypophysectomy had been performed in 31 patients (62 eyes). The length of the observation period appears from Fig. I. The patients submitted to hypophysectomy were observed for 12 to I 3 I months (mean 58 ; S.D. 23.5), while the nonoperated patients were observed for 7 to 89 months

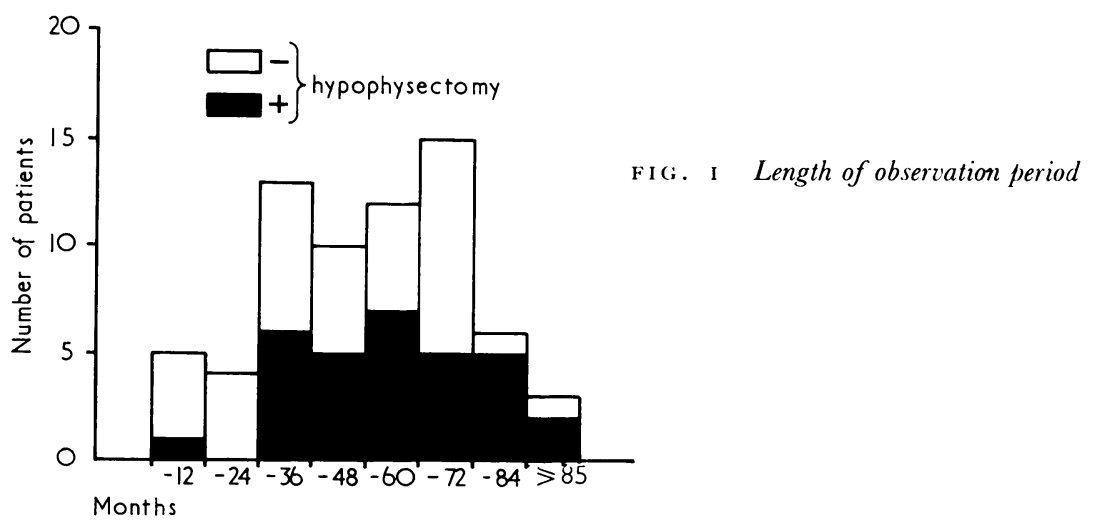

Received for publication December 10,1970 
(mean 43 ; S.D. $21 \cdot 8$ ). Even though the observation time is longer in the hypophysectomized group and despite a slight predominance of old patients in the nonoperated group, it seems justified to make a certain comparison between the hypophysectomized and nonhypophysectomized patients. Reports on the hypophysectomized patients were previously published by Lundbaek, Malmros, Andersen, Rasmussen, Bruntse, Madsen, and Jensen (1969) and Madsen (1970).

\section{General data}

The following presentation of general data is based on the findings at the last examination.

The age distribution is shown in Table $I ; 75$ per cent. of the patients were under 50 years.

The duration of diabetes is shown in Table II; 84 per cent. had had diabetes for 20 years or more.

Table I Age distribution of 68 patients

\begin{tabular}{|c|c|c|c|}
\hline \multirow{2}{*}{ Age (yrs) } & \multicolumn{2}{|c|}{ Hypophysectomy } & \multirow{2}{*}{ Total } \\
\hline & Performed & Not performed & \\
\hline $20-29$ & 4 & 4 & 8 \\
\hline $30-39$ & 15 & 16 & $3^{1}$ \\
\hline $4^{0-49}$ & 6 & 6 & 12 \\
\hline $50-59$ & 5 & 5 & I0 \\
\hline $60-69$ & I & 5 & 6 \\
\hline $70-$ & & I & $\mathbf{I}$ \\
\hline Total & $3^{I}$ & 37 & 68 \\
\hline Mean & $3^{8 \cdot 8}$ & $43 \cdot 4$ & \\
\hline $\begin{array}{l}\text { Standard } \\
\text { deviation }\end{array}$ & $9 \cdot 34$ & $9 \cdot 37$ & \\
\hline Range & $26-64$ & $23-81$ & \\
\hline
\end{tabular}

Table II Duration of diabetes in 68 patients

\begin{tabular}{|c|c|c|c|}
\hline \multirow{2}{*}{$\begin{array}{l}\text { Duration } \\
\text { (yrs) }\end{array}$} & \multicolumn{2}{|c|}{ Hypophysectomy } & \multirow{2}{*}{ Tota } \\
\hline & Performed & Not performed & \\
\hline $0-9$ & & $\mathbf{I}$ & $\mathbf{I}$ \\
\hline $10-19$ & 4 & 6 & IO \\
\hline $20-29$ & 19 & 20 & 39 \\
\hline $30-$ & 8 & IO & 18 \\
\hline Total & $3^{1}$ & 37 & 68 \\
\hline $\begin{array}{l}\text { Mean } \\
\text { Standard } \\
\quad \text { deviation }\end{array}$ & $\begin{array}{c}26 \cdot 4 \\
6 \cdot 44\end{array}$ & $\begin{array}{c}24 \cdot 6 \\
7 \cdot 22\end{array}$ & \\
\hline Range & $12-45$ & $6-38$ & \\
\hline
\end{tabular}

The patients' ages at the time of diagnosis of diabetes is shown in Table III; 75 per cent. were under 20 years when diabetes was diagnosed.

Table III Age at which diabetes was diagnosed in 68 patients

\begin{tabular}{|c|c|c|c|}
\hline \multirow{2}{*}{ Age at diagnosis (yrs) } & \multicolumn{2}{|c|}{ Hypophysectomy } & \multirow{2}{*}{ Total } \\
\hline & Performed & Not performed & \\
\hline $0-9$ & 17 & 10 & 27 \\
\hline $10-19$ & 8 & 16 & 24 \\
\hline 20-29 & 3 & 2 & 5 \\
\hline $30-39$ & 2 & 4 & 6 \\
\hline $40-49$ & $\mathbf{I}$ & 2 & 3 \\
\hline $50-59$ & & 3 & 3 \\
\hline Total & 31 & 37 & 68 \\
\hline Mean & $12 \cdot 5$ & $18 \cdot 8$ & \\
\hline Standard deviation & $9 \cdot 22$ & $15 \cdot 79$ & \\
\hline Range & $1-40$ & $\mathrm{I}-59$ & \\
\hline
\end{tabular}

The occurrence of proteinuria, increased serum creatinine values, and arterial hypertension is listed in Table IV (overleaf): 60 per cent. had proteinuria; I9 per cent. had serum creatine values above $1.3 \mathrm{mg}$./100 ml.; 40 per cent. a blood pressure above $150 / 100 \mathrm{~mm}$. Hg (Lundbaek, I953); and 20 per cent. a diastolic pressure above $100 \mathrm{~mm}$. $\mathrm{Hg}$. 
Table IV Proteinuria, serum creatinine, and blood pressure

\begin{tabular}{|c|c|c|c|c|}
\hline \multirow{2}{*}{ Test } & & \multicolumn{2}{|c|}{ Hypophysectomy } & \multirow{3}{*}{$\begin{array}{l}\text { Total } \\
27\end{array}$} \\
\hline & & Performed & Not performed & \\
\hline \multirow[t]{2}{*}{ Proteinuria } & Absent & 9 & 18 & \\
\hline & Present & 22 & 18 & 40 \\
\hline \multirow{2}{*}{$\begin{array}{l}\text { Serum creatinine } \\
\text { (mg. per cent.) }\end{array}$} & $>_{1} \cdot 3$ & 24 & 26 & 50 \\
\hline & $\leqslant \mathrm{r} \cdot 3$ & 7 & 5 & 12 \\
\hline \multirow{3}{*}{$\begin{array}{l}\text { Blood pressure } \\
(\mathrm{mm} . \mathrm{Hg})\end{array}$} & $\leqslant 150 / 100$ & 20 & 18 & 38 \\
\hline & $>150 / 100$ & II & 14 & 25 \\
\hline & Diastolic pressure $>$ I00 & 4 & 8 & 12 \\
\hline
\end{tabular}

The treatment is shown in Table V. Insulin was given in all but two patients. After hypophysectomy the insulin requirements fell to about one half of the preoperative dose, which explains the low dosage of insulin in the group subjected to hypophysectomy.

Table $\mathbf{V}$ Treatment of 68 patients with diabetes

\begin{tabular}{|c|c|c|c|}
\hline \multirow{2}{*}{ Treatment } & \multicolumn{2}{|c|}{ Hypophysectomy } & \multirow{2}{*}{ Total } \\
\hline & Performed & Not performed & \\
\hline Diet $\ldots, \ldots$ & & $\mathbf{I}$ & $\mathbf{I}$ \\
\hline Oral antidiabetic drug & & I & I \\
\hline Insulin - 40 I.U. & 27 & 21 & 48 \\
\hline$>40$ I.U. & 4 & 14 & 18 \\
\hline Total & 31 & 37 & 68 \\
\hline
\end{tabular}

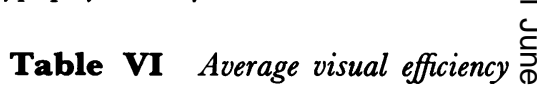
in individual eyes (per cent.)

\begin{tabular}{|c|c|c|}
\hline \multirow{2}{*}{ Examination } & \multicolumn{2}{|c|}{ Hypophysectomy } \\
\hline & Performed & Not performe \\
\hline First & 55 & $5^{8}$ \\
\hline Last & 47 & 40 \\
\hline
\end{tabular}

\section{Ocular data}

VISUAL AGUITY

Fig. 2 shows the visual acuity in the ${ }_{1} 36$ individual eyes of the 68 patients at the first and last examinations.

During the period of observation, a fall in visual acuity to less than $0 \cdot 1$ was seen in $22 \stackrel{3}{3}$ eyes ( 10 in hypophysectomized and 12 in nonhypophysectomized patients). The loss of 0 vision occurred during the first year in two of the patients subjected to operation, but in six in the nonoperated group. During the second year, two eyes in both groups lost vision, 絮 whereas blindness did not occur until after 2 years in six and four eyes, respectively.

Visual improvement from less than $0 \cdot 1$ to more than $0 \cdot 1$ was observed in four eyes (three in hypophysectomized patients).

Fig. 3 shows the visual acuity in the patient's best eye at the first and last examinations; it is seen that four patients were blind (visual acuity less than $0 \cdot I$ in both eyes) at the first 0 examination, but eleven were blind at the last check-up. Ten of these eleven blind patients were under 50 years and had had diabetes since before the age of 20 years.

If visual efficiency (Snell and Sterling, 1925) is used instead of visual acuity in the assessment of vision in the individual eyes in the two groups, the averages obtained are those given in Table VI. It is seen that the decrease in vision was fairly moderate in both 
groups, viz. 8 per cent. in the hypophysectomized and I 8 per cent. in the nonhypophysectomized patients.

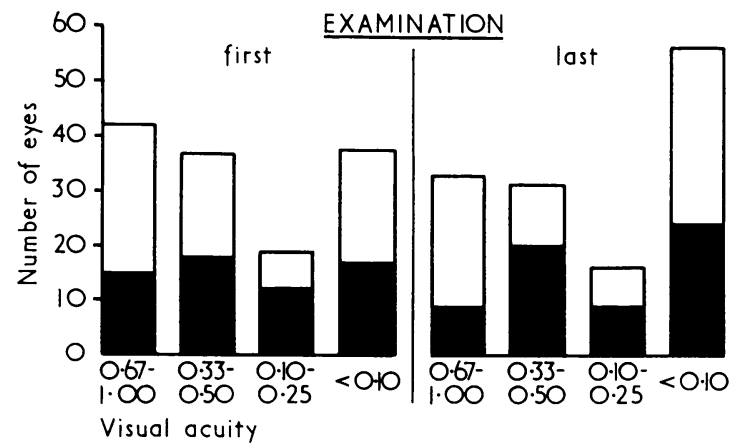

FIG. 2 Visual acuity in individual eyes

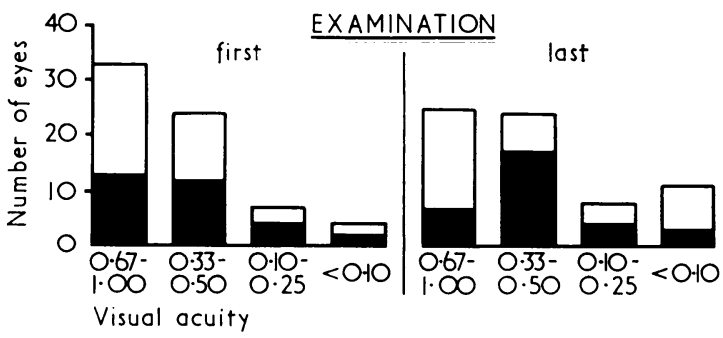

FIG. 3 Visual acuity in patients (vision of best eye)

RETINOPATHY

\section{Background retinopathy}

This was very frequent in both groups of patients.

Severe arterial changes seemed to be more frequent in the hypophysectomized patients, and the phlebopathy was somewhat more pronounced in the nonoperated patients.

Red dots, haemorrhages, and exudates were numerous in patients suffering from proliferative retinopathy in the first stages. As the proliferative retinopathy developed, with formation of connective tissue and vitreous detachment, the background retinopathy tended to decrease.

After hypophysectomy an unmistakable improvement in the background retinopathy was observed. Most of the red dots and haemorrhages disappeared, the phlebopathy abated, and the hard exudates decreased in number. An example of this development is shown in Figs 4 and 5. After some years, red dots and haemorrhages reappeared in many of the hypophysectomized patients, but they were less numerous than before the operation.

\section{Proliferative retinopathy}

This differed widely, not only from patient to patient, but also in the two eyes of the individual patient. The development of the proliferations seemed to follow a certain pattern. They often started as fine vessels either on the disc or on the retina outside the disc area. Then the vessels gradually spread, and connective tissue appeared around the central part of the vessels, while the peripheral networks or coils were still naked. At first the connective tissue was thin and veil-like, but it gradually became denser, although the development was still dominated by the vascular proliferations. Then some vessels 
(4)

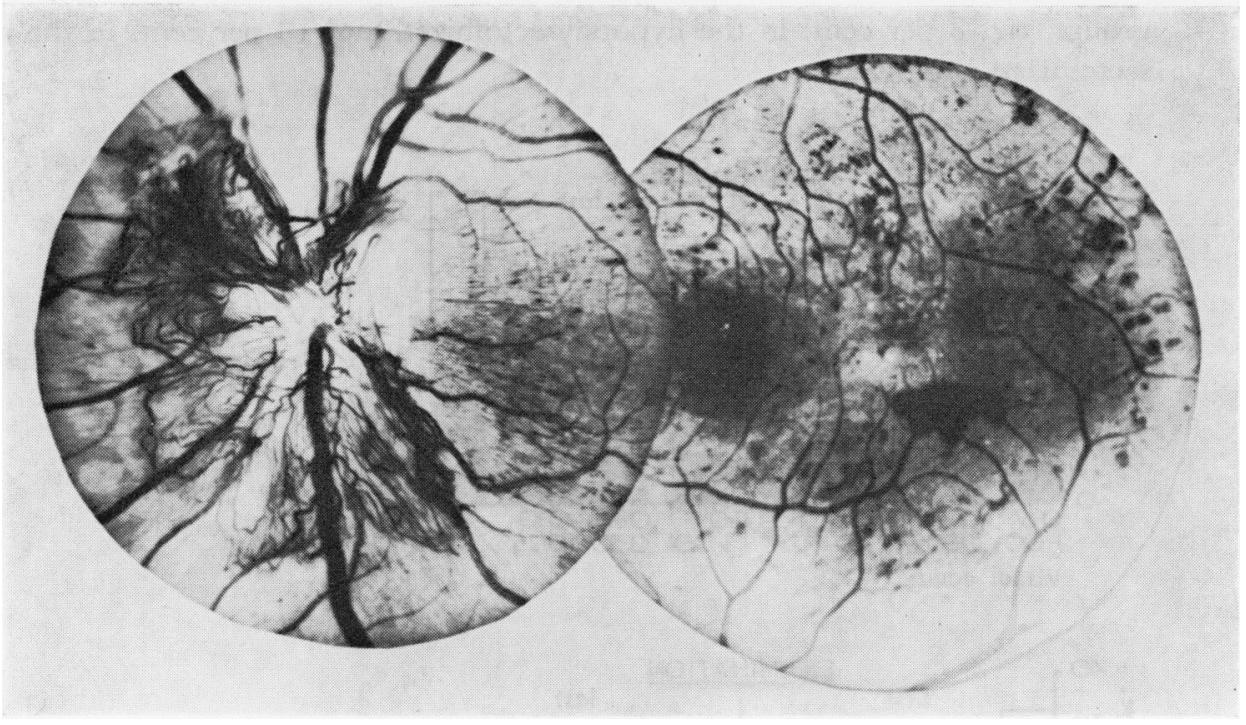

(5)

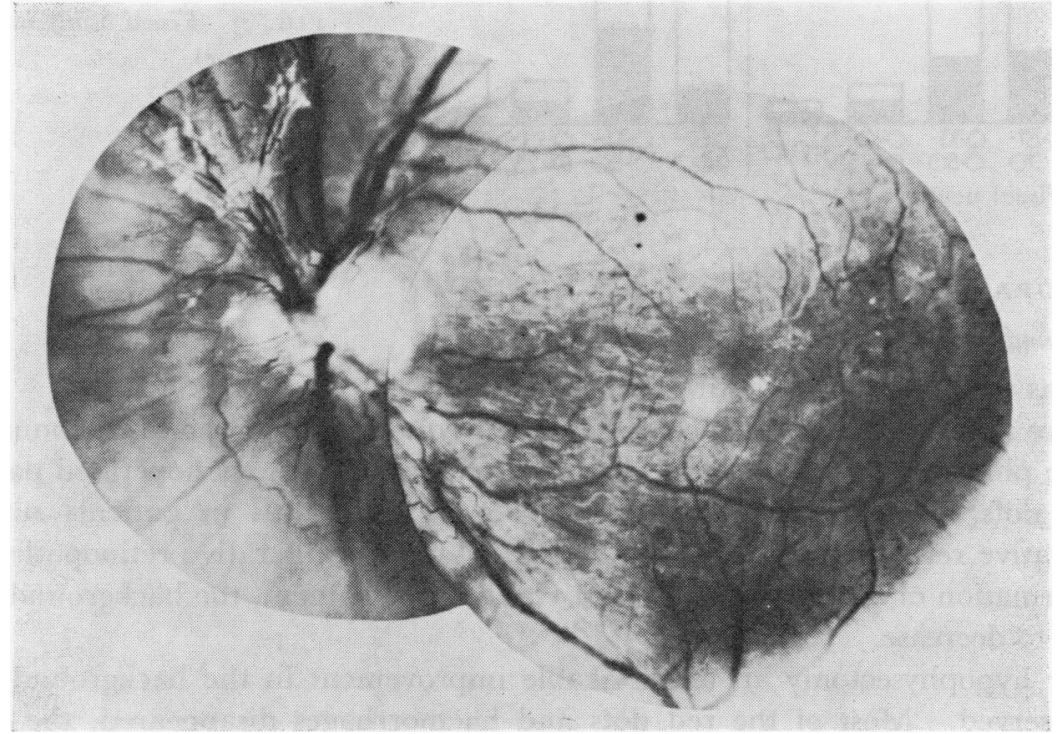

FIG. 4 Left fundus in a woman aged 30 (before hypophysectomy)

FIG. 5 Same eye as in Fig. 4, 12 months later (I I months after hypophysectomy)

disappeared, and the progressive phase was followed by regression. The connective tissue shrank with ensuing traction on the retina and the retinal vessels.

As a rule, the development of the proliferative retinopathy was most progressive when the changes were localized in the disc area, and it was most severe in eyes with large retrovitreal haemorrhages (Figs 6 and 7, opposite). When the eyes had reached the stage of regression, their condition might remain unchanged for several years.

Fig. 8 (overleaf) shows the occurrence of proliferative retinopathy in individual eyes in different stages (Dobree, I964). At the first examination, proliferations consisting of naked vessels (Stage I) were seen in $3^{8}$ per cent. of all eyes and connective-tissue proliferations (Stages II and III) in 48 per cent. At the last examination, naked vessels were present in 22 per cent. of the eyes and connective tissue in $5^{1}$ per cent. The fundus could not be 


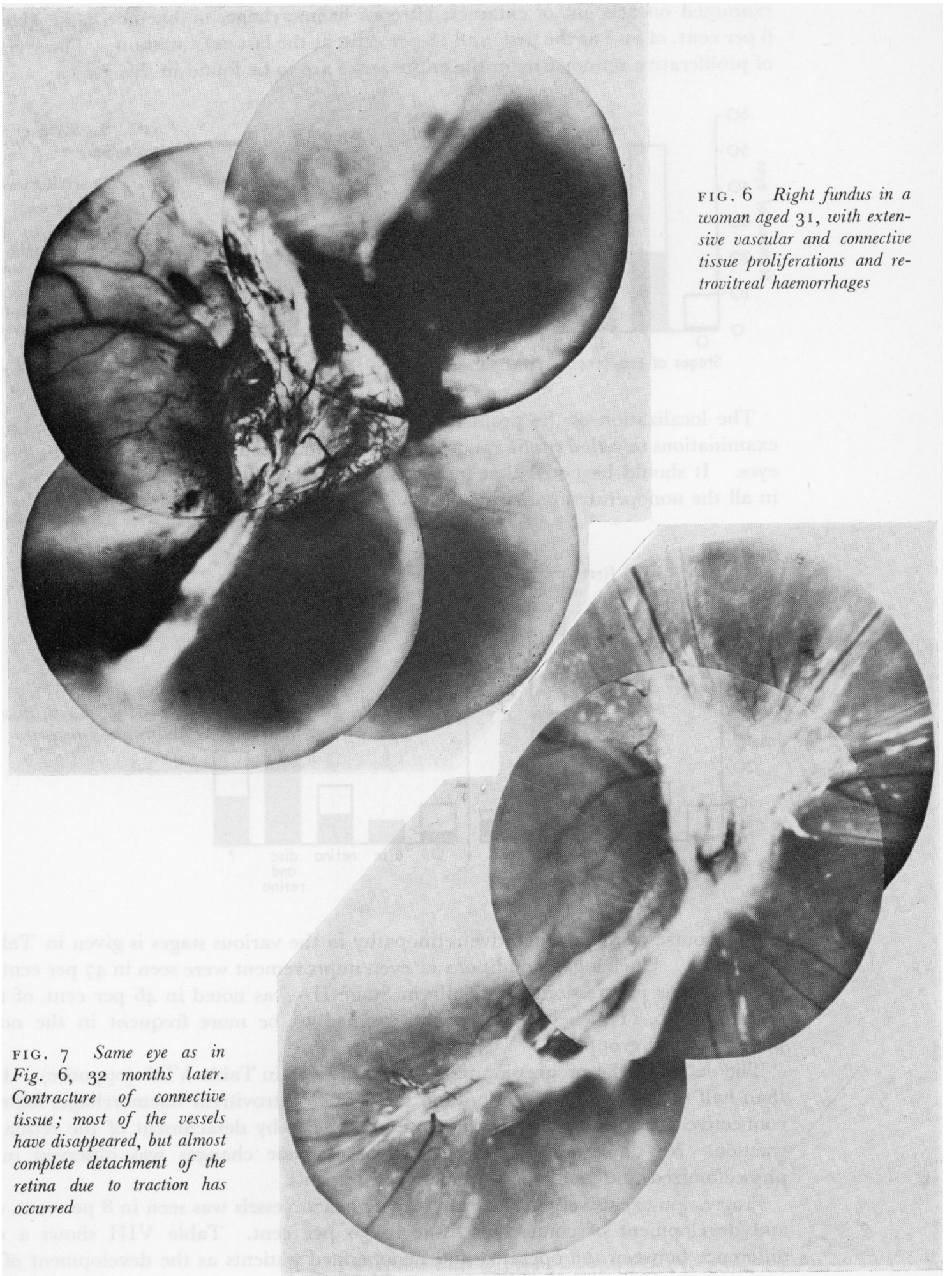


examined on account of cataract, vitreous haemorrhage, or haemorrhagic glaucoma in 6 per cent. of eyes at the first, and 18 per cent. at the last examination. The severest cases of proliferative retinopathy in the entire series are to be found in this group.
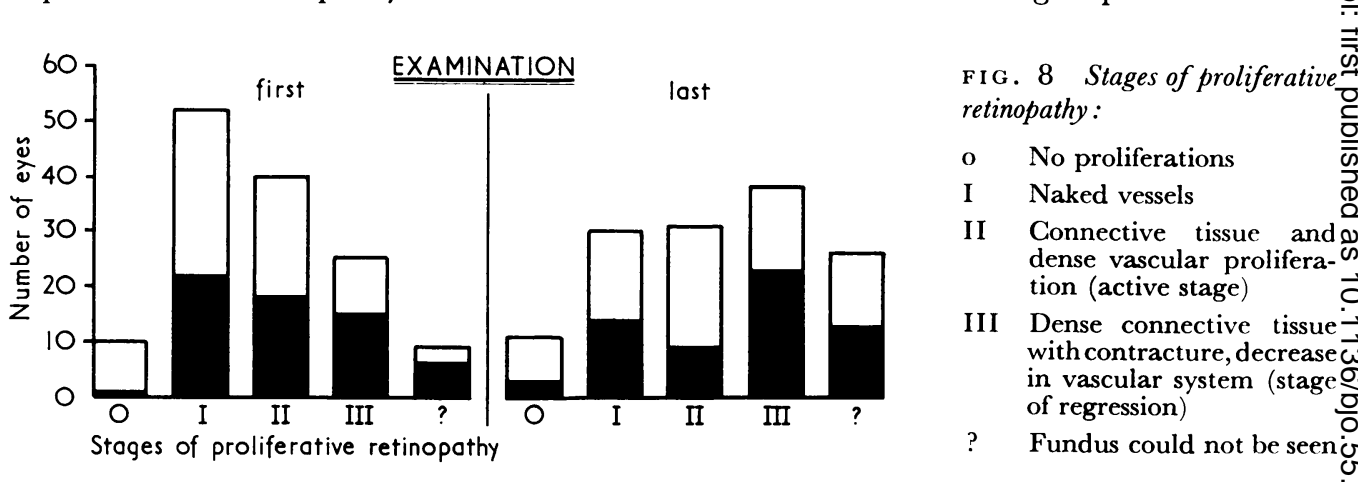

The localization of the proliferations is shown in Fig. 9. Both the first and the last examinations revealed proliferations on both the disc and retina in the vast majority of theo eyes. It should be noted that localized prepapillary proliferations became more severe in all the nonoperated patients.

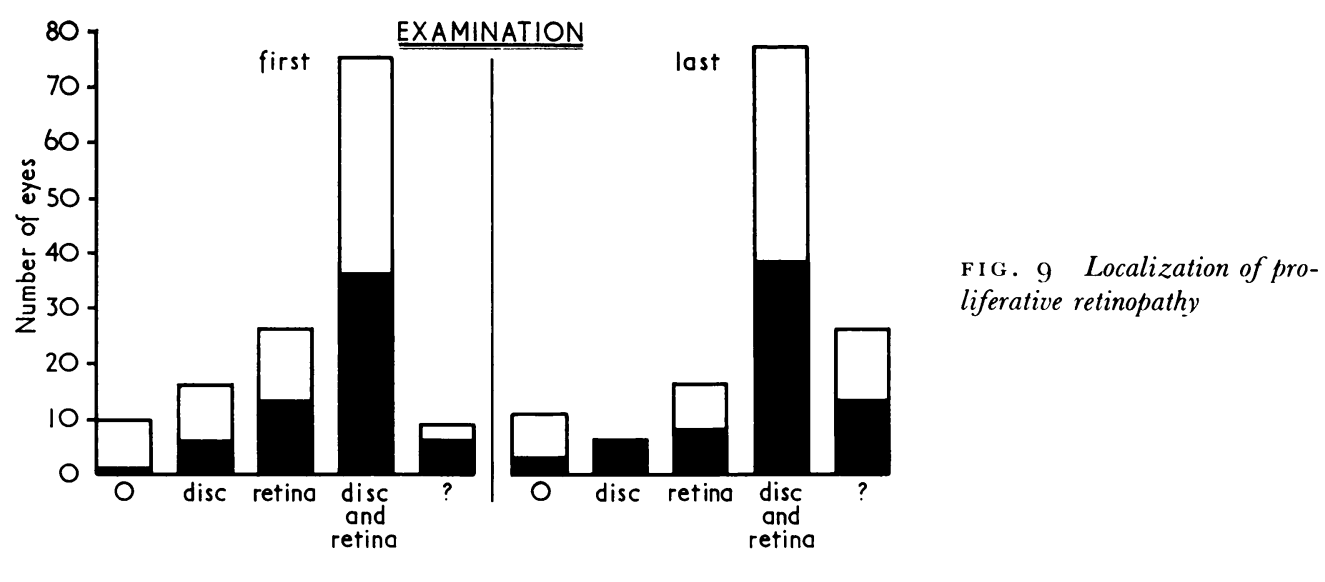

The course of the proliferative retinopathy in the various stages is given in Table VII 0 (opposite). Unchanged conditions or even improvement were seen in 47 per cent. of the eyes, whereas progression-especially in Stage II-was noted in 46 per cent. of the eyes (Figs 6, 7, I0, I I). Severe progression seemed to be more frequent in the nonhypo- No physectomized group.

The causes of the progression in 63 eyes are given in Table VIII (opposite). In more N than half of the eyes, the deterioration was due to retrovitreal haemorrhages followed byo connective tissue formation and, in some cases, also by detachment of the retina due too traction. No difference in the occurrence of these changes was observed in hypo-市 physectomized and nonhypophysectomized patients.

Progression exclusively in the form of new naked vessels was seen in 8 per cent. of eyes, $\stackrel{0}{0}$ and development of connective tissue in 30 per cent. Table VIII shows a distinct苂 difference between the operated and nonoperated patients as the development of vessels $\stackrel{\widetilde{\Phi}}{\circ}$ 
Table VII Course of proliferative retinopathy in 136 eyes in 68 patients

\begin{tabular}{|c|c|c|c|c|c|c|}
\hline \multirow{2}{*}{ Hypophysectomy } & \multirow{2}{*}{$\begin{array}{l}\text { Stage at first } \\
\text { examination }\end{array}$} & \multicolumn{5}{|l|}{ Course } \\
\hline & & No change & Improvement & Progression & $\begin{array}{l}\text { Severe } \\
\text { progression }\end{array}$ & ? \\
\hline \multirow[t]{5}{*}{ Performed } & o & $\mathbf{I}$ & o & o & o & \\
\hline & I & IO & 4 & 6 & 2 & \\
\hline & II & 4 & 2 & 2 & 10 & \\
\hline & $\begin{array}{l}\text { III } \\
?\end{array}$ & 9 & $\mathbf{o}$ & $\mathbf{I}$ & 5 & 6 \\
\hline & Total (62 eyes) & 24 & 6 & 9 & 17 & 6 \\
\hline \multirow[t]{5}{*}{ Not performed } & o & 7 & $\mathbf{o}$ & $\mathbf{I}$ & I & \\
\hline & I & 10 & 4 & I & 15 & \\
\hline & II & 3 & I & 4 & 14 & \\
\hline & $\underset{?}{\text { III }}$ & 9 & $\mathbf{o}$ & o & I & 3 \\
\hline & Total (74 eyes) & 29 & 5 & 6 & 31 & 3 \\
\hline Total & 136 eyes & 53 & I I & 15 & $4^{8}$ & 9 \\
\hline
\end{tabular}

Stages as in Fig. 8

Table VII Causes of progression in proliferative retinopathy in 63 eyes

Cause

\begin{tabular}{|c|c|c|}
\hline \multicolumn{2}{|c|}{ Hypophysectomy } & \multirow{2}{*}{ Tota } \\
\hline Performed & Not performed & \\
\hline 12 & 12 & 24 \\
\hline 6 & 4 & 10 \\
\hline 2 & 3 & 5 \\
\hline 4 & 15 & 19 \\
\hline $\mathbf{o}$ & 3 & 3 \\
\hline 2 & $\mathbf{o}$ & 2 \\
\hline 26 & 37 & 63 \\
\hline
\end{tabular}

Retrovitreal haem. + vascular and conn. tissue proliferation

Retrovitreal haem. + vessels and conn. tissue + detachment of retina

Naked vessels

Vessels and conn. tissue

Vessels, conn. tissue + detachment of retina

Detachment of retina without new proliferations

Total

Table IX Eyes with arrest in proliferative diabetic retinopathy-assessed at different stages (number of eyes)

\begin{tabular}{|c|c|c|c|c|c|c|c|c|c|c|}
\hline \multirow{2}{*}{ Hypophysectomy } & \multirow{2}{*}{$\begin{array}{l}\text { Stage at first } \\
\text { examination }\end{array}$} & \multicolumn{8}{|c|}{ Duration of observation period (mths) } & \multirow{2}{*}{ Total } \\
\hline & & -12 & -24 & -36 & $-4^{8}$ & -60 & -72 & -84 & $>85$ & \\
\hline Performed & $\begin{array}{l}\text { o } \\
\text { I } \\
\text { II } \\
\text { III }\end{array}$ & 2 & & $\begin{array}{l}3 \\
1 \\
1\end{array}$ & $\begin{array}{l}5 \\
2\end{array}$ & $\begin{array}{l}\text { I } \\
\text { I } \\
\text { I }\end{array}$ & $\begin{array}{l}2 \\
1 \\
3\end{array}$ & $\begin{array}{l}3 \\
3\end{array}$ & $\mathbf{I}$ & $\begin{array}{r}1 \\
14 \\
6 \\
9\end{array}$ \\
\hline Not performed & $\begin{array}{l}\text { o } \\
\text { I } \\
\text { II } \\
\text { III }\end{array}$ & $\begin{array}{l}\text { I } \\
\text { I }\end{array}$ & $\mathbf{I}$ & $\begin{array}{l}\text { I } \\
3 \\
\text { I }\end{array}$ & $\begin{array}{l}\text { I } \\
\text { I } \\
\text { I }\end{array}$ & 2 & $\begin{array}{l}4 \\
7 \\
1 \\
7\end{array}$ & & I & $\begin{array}{r}7 \\
14 \\
4 \\
9\end{array}$ \\
\hline Total & & 4 & $\mathbf{I}$ & 10 & Io & 5 & 25 & 6 & 3 & 64 \\
\hline
\end{tabular}


and connective tissue without preceding retrovitreal haemorrhage predominated in the nonoperated group.

Table IX shows the observation period for 64 eyes with arrest or improvement in the development of the proliferations. The Table includes eight eyes in which no proliferations were seen during the entire period. Most of the patients were under observation for several years, and it appears that unchanged conditions were observed in many patients who had not been subjected to hypophysectomy.

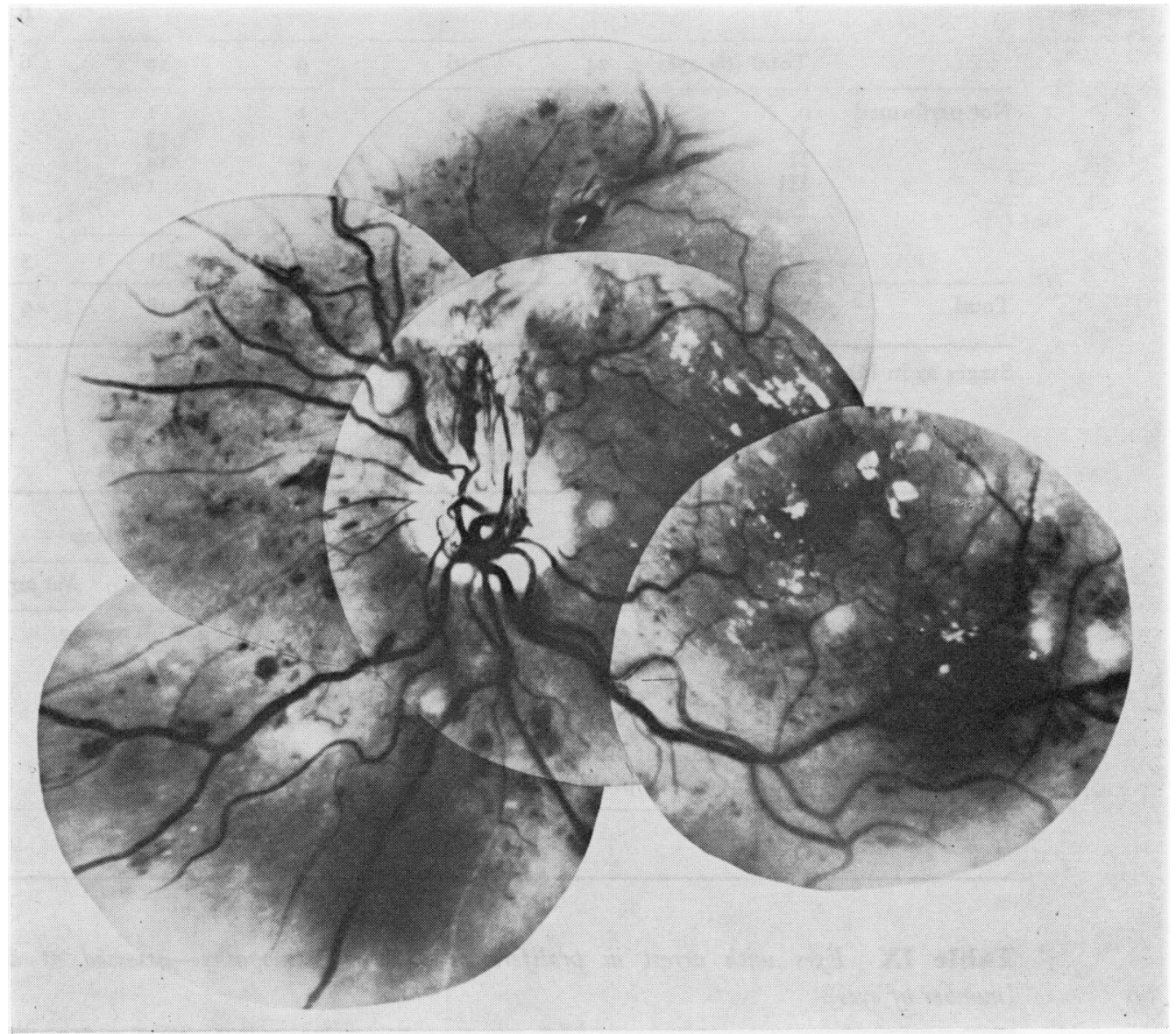

FIG. Io Left fundus in a man aged 46. Vascular proliferations and veils of connective tissue. Pronounced background retinopathy (before hypophysectomy)

\section{Discussion}

The present study of 68 patients with proliferative diabetic retinopathy showed that $49 \stackrel{0}{C}$ retained a visual acuity of 0.33 in one or both eyes, and that at the last examination only $\stackrel{\mathbb{\Phi}}{\rightarrow}$ eleven patients were blind. The decrease in vision was most pronounced in the group of nonhypophysectomized patients.

Deckert, Simonsen, and Poulsen (1967) also demonstrated that vision may be preserved for several years in diabetics with proliferative retinopathy, particularly in eyes with lesions in the retinal periphery. Kornerup (1958) reported that temporary visual improvement 


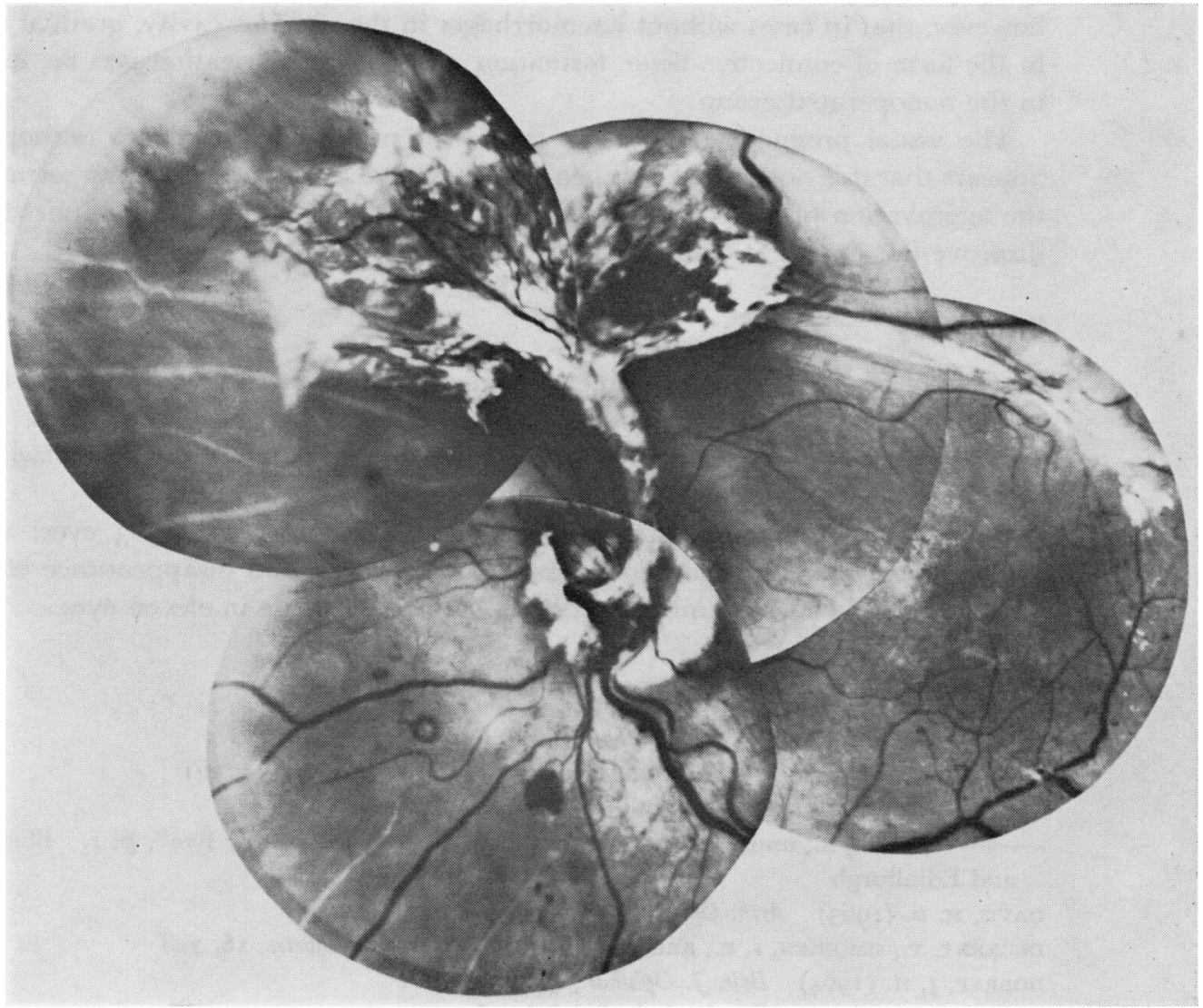

FIG. I I Same eye as in Fig. 10, 31 months later. Considerable progression in the proliferations; retinal detachment due to traction upwards temporally. Several arteries are transformed into white bands; otherwise the background retinopathy has improved

occurred in five patients. Among 242 patients with proliferative diabetic retinopathy observed for I to I 3 years, Beetham ( 1963 ) found that 82 retained a visual acuity of $6 / 12$ or more, and 156 one of more than 6/6o. He estimated that the average deterioration of the proliferative retinopathy from slight to extreme took approximately 5 years.

During recent years, reports have appeared on patients with arrest or even regression of the proliferations. Fischer ( 196 I) mentioned four cases with regression in the retinopathy, and Dobree (1964) found that, in four eyes observed for ro to 36 months, new-formed vessels on the retina had disappeared or considerably abated. Davis (1965) observed 55 patients for 6 to 36 months and found stationary conditions in fourteen eyes, and regression of new-formed vessels in four. Among $35^{1}$ patients, Beetham (1963) observed spontaneous arrest in the proliferative retinopathy in 35 , for more than 4 years in eight.

In the present series, proliferative retinopathy was stationary in 45 eyes. Proliferations did not develop in eight eyes during the observation period, and new-formed vessels disappeared in eleven eyes. Progression of the proliferative retinopathy was observed in nearly one half of the eyes in both hypophysectomized and nonhypophysectomized patients. Haemorrhages in the vitreous cavity with subsequent vascular and connective-tissue proliferations were seen with the same frequency in the two groups. It is remarkable, 
however, that in cases without haemorrhages in the vitreous cavity, gradual deterioration in the form of connective-tissue formation and neovascularization was far more frequent in the nonoperated group.

The visual prognosis is poor for eyes with proliferative diabetic retinopathy, but it appears that it is not as bad as is generally assumed. Hypophysectomy seems to postpone the aggravation of the fundus lesions, but strict clinical studies are required to prove or disprove this apparent tendency.

\section{Summary}

A series of 68 patients with proliferative diabetic retinopathy was observed for from 7 to $\vec{\odot}$ I 3 I months. In 31 of the patients, hypophysectomy had been performed. Decrease in $\overrightarrow{\vec{\omega}}$ vision was observed in operated as well as nonoperated patients, but at the last examination only eleven patients were blind (visual acuity below $0 \cdot 1$ in both eyes).

Progression of the proliferative retinopathy was observed in 63 eyes; arrest in the of development of the proliferations was seen in 45 eyes, and disappearance of new-formed vessels without concomitant formation of connective tissue in eleven eyes.

\section{References}

BeETHAM, W. P. (1963) Brit. F. Ophthal., 47, 6 I I

GAIRD, F. I., BURDITT, A. F., and DRAPER, G. J. (1968) Diabetes, 17 , 121

- and GARRETT, C. J. (1963) Ibid., 12, 389

— PIRIE, A., and RAmsell, T. G. (1969) "Diabetes and the Eye", p. I. Blackwell, Oxford and Edinburgh

DAvis, M. D. (1965) Arch. Ophthal. (Chicago), 74, 74I

DECKert, T., SIMONSEN, S. E., and POULSEN, J. E. (1967) Diabetes, 16, 728

DOBREE, J. H. (1964) Brit. F. Ophthal., 48, 637

Fischer, F. (196I) v. Graefes Arch. Ophthal., 163, 397

KORNERUP, T. (1958) Acta ophthal. (Kbh.), 36, 87

LEe, P.-F., McMeel, J. W., SChepens, c. L., and Field, R. A. (ig66) Amer. F. Ophthal., 62, 207

Lindstedt, E. (1969) “Causes of Blindness in Sweden”, Acta ophthal. (Kbh.), Suppl. 104, p. 22

LUNDBAEK, K. (1953) “Long-Term Diabetes", p. 30. Munksgaard, Copenhagen

- MALMROS, R., ANDERSEN, H. C., RASMUSSEN, J. H., BRUNTSE, E., MADSEN, P. H., and JENSEN, V. A.

(1969) "Excerpta Medica Int. Congress Series, No. I 72 S, "Diabetes: Proc. VI Congr. int.

Diabetes Foundation, Stockholm, 1967", p. 127

MADSEN, P. H. (1970) Acta med. scand., 188, 345

SNELl, A. G., and STERLing, s. (1925) Arch. Ophthal. (N.Y.), 54, 443

VEDEL-JENSEN, N. (1962) Dan. med. Bull., 9, 185

Winter, F. c. (1960) J. Amer. med. Ass., 174, 143 